\title{
The Talent Cultivation Mode Reform and Graduates' Employment of Bohai University
}

\author{
Xiaoshu Wang ${ }^{\mathrm{a}^{*}}$ and Le Wang ${ }^{\mathrm{b}}$ \\ Bohai University, Jinzhou, Liaoning, China \\ a49718990@qq.com, blewang1982@163.com
}

\begin{abstract}
Keywords: Graduates' employment; University-enterprise cooperation; Innovation training; Complete credit system; Talent cultivation mode
\end{abstract}

\begin{abstract}
This paper introduces the reform of talent cultivation mode in Bohai University, which including divide students into research orientation and practice orientation, implement complete credit system, separate teaching and examination, implement excellent talent training program, implement ISEC program, implement centralized internship and social practice, promote order training through university-enterprise cooperation, establish public experimental platform, carry out innovation and entrepreneurship education, and encourage students to declare innovative and entrepreneurship training projects. Introduce the employment service guidance system of Bohai University, such as implement full employment guidance services, implement full employment information service, and provide adequate funding and personnel protection, help poor family students, support students to start their own businesses, analysis and evaluation graduates' employment. Finally, analyzes the employment situation of Bohai University graduates and the evaluation from employer. Bohai University graduates are mostly employed in private enterprises, the salary satisfaction of graduates basically showed a normal distribution, most graduates are feeling all right, and employer's comprehensive evaluation of graduates has improved.
\end{abstract}

\section{Introduction}

Bohai University is a comprehensive university administered by Liaoning Province government, located in Jinzhou City, Liaoning Province, China. Bohai University has done a lot of work in talent cultivation mode reform, improves the students' innovative ability and practical ability, and makes notable achievements in students' employment. In 2015, Bohai University was awarded the nation's top 50 employment universities by Ministry of Education.

\section{The Talent Cultivation Mode Reform of Bohai University}

Divide Students into Research Orientation and Practice Orientation. At the end of 2010, according to the social needs of graduates, Bohai University divided students into two categories, research orientation and practice orientation. Research orientation students are focus on academic ability training and innovative spirit education, the future direction of development is to become graduate students in universities and research institutions. Practice orientation students are focus on professional knowledge and skills training, the future direction of development is to become excellent engineers, senior technicians and managers. Students can choose their own orientation, and also have the right to change orientation.

Implement Complete Credit System. The complete credit system reform is the most subversive reform in the university history. All courses in the training program are providing through open tender, and one course has at least two teachers. The teachers need to submit the syllabus and grading standards into the course elective system, and provide a 20 minutes trial lecture, and then the students decide what course to choose and who will be the teacher. In the first four weeks of each semester, students can also change courses or teachers. Complete credit system highlights the "student oriented" concept, dilute the 
major boundaries, and meet the needs and personality development of students. Teachers need to constantly improve their ability, otherwise they will be eliminated.

Separate Teaching and Examination. Courses are divided into two types of examination and no examination. All the examination courses need to establish a test database, questions and answers in the test database should be in the standard format, and the questions should contain at least 20 examination papers. Teachers only provide regular grade ( $70 \%$ of total score), and final exam questions are extracted and assessed by computer or other teacher (30\% of total score), if extracted by computer (such as Foreign Language, Management), each student's examination paper will be different. So students have to pay more attention to the regular grade, ensure adequate attendance, and prepare a lot of review for the final exam.

Implement Excellent Talent Training Program. Bohai University established the Excellence College in 2012, responsible for the university elite training program, this program only recruits 60 students from freshman, set higher talent training objectives, make them to become future political elite, well-known experts and scholars and outstanding enterprises leader with great ambitious, nice moral character, solid theoretical knowledge, outstanding innovation ability, and strong social competitiveness. The Excellence College will provide 10,000 YUAN to support the talent to study overseas for one year. In 2013, several secondary colleges established other excellent talent training programs, such as excellent management talent program, excellent engineer program and excellent teacher program.

Implement ISEC Program. ISEC is the abbreviation of International Scholarly Exchange Curriculum, ISEC program actively learns from international famous university education experience, presents a new assessment system. ${ }^{[1-5]}$ At present, Bohai University has two ISEC programs, accounting and finance, totally 210 students. These students can go abroad when they are junior.

Implement Centralized Internship and Social Practice. Students must attend centralized internships when they are senior. Some special practice orientation students need 15 months' internship, other practice orientation students need 10 months' internship, and research orientation students need 5 months' internship. The university also encourages students to participate in social practice, serve the society.

Promote Order Training Through University-Enterprise Cooperation. Bohai University has signed many personnel training orders with companies, and revise training program with the talent need from industry, enhance practice time. Bohai University signed an agreement with the Chinasoft International Co. Ltd. and Beijing Datang Telecom, using "2.5+1.5" joint training mode to educate software students, the first 2.5 years, students study in Bohai University, and the next 1.5 years are work in the two companies, and after graduate, students can become formal employees of the company. Bohai University established the Banking College with Jinzhou Bank, using "2+2" joint training mode to educate accounting and financial students, and established the Argyle College with Argyle Hotel Group, using "2+2" joint training mode to educate tourism and hotel management students. Each year, about 600 students can have jobs directly from these programs.

Establish Public Experimental Platform. In the past 5 years, Bohai University established five public experimental platforms for different college students, including journalism and communication experiment teaching center, electrical and electronic experiment teaching center, public computer experiment teaching center, economic and management experimental teaching center and public inspection center. The university invested 10 million YUAN to establish a professional studio, produced the "Live Jinzhou City" and "Nice Person in Jinzhou" two programs for Jinzhou TV station. The mock court of the university also undertakes the trial of ordinary civil cases of Jinzhou Intermediate People's Court. These experimental platforms improve the professional skills of students.

Carry Out Innovation and Entrepreneurship Education. Bohai University established a full employment guidance mechanism, the Student Employment Department offers innovative thinking training courses for freshman, offers career planning courses for sophomore, and offers employment guidance and entrepreneurial guidance for junior and senior students. Also holds job hunting competition, invite experts and successful person to give lectures, and provides vocational skills training for poor family students. 
Encourage Students to Declare Student Innovative and Entrepreneurship Training Projects. Bohai University requires each student to receive 2 innovative credits by participate in the national innovative and entrepreneurship training projects and other innovation competition. The university assigns professional teachers to guide students' innovative societies and innovation groups. In 2015, Bohai University received 39 national innovation projects and 80 provincial innovation projects, and won a number of national innovation competition awards. Many students participate in their undergraduate tutor research projects, and have published many academic papers.

\section{The Employment Service Guidance System of Bohai University}

Implement Full Employment Guidance Services. Bohai University formed a leading group on students' employment. Its members include vice-president, director of employment department, director of the academic affairs office, director of the student affairs office, director of the center for experimental management, and deans of the secondary colleges. The employment department consists of internship management department, employment market department, employment information department, employment training department and vocational training department. The university has established a number of employment negotiations room.

Implement Full Employment Information Service. Established Bohai University graduate employment website, including more than 2300 enterprise information, site hits are more than 200 thousand times per year. Bohai University held one large graduation recruitment meeting, two internship recruitment meeting, and over 100 special recruitment meeting every year. The university also established over 120 centralized internship base.

Provide Adequate Funding and Personnel Protection. Bohai University's annual special funds of employment are more than 1.1 million yuan, and recruited 60full-time and part-time employment teachers, of which 13 teachers are full-time employment service personnel, 35 teachers are employment guidance course teacher, and 29 teachers have relevant professional qualification certificate. The university select employment information officer from junior and senior class, use QQ group, WeChat, and Fetion to transfer related employment information to each of the graduates.

Help Poor Family Students. The university increase psychological counseling and guidance efforts to the poor family students and carry out special employment training to help them overcome inferiority complex. In 2013, the university provided a 500 yuan of employment subsidies to 1010 poor family students.

Support College Students to Start Their Own Businesses. Bohai University established a university S\&T Park and a college incubation base with Beijing Yihaifeihong Co. Ltd., provide entrepreneurial training services for more than 150 students, some of them become a typical college students entrepreneurship. "China Youth Daily", "Guangming Daily", "Xinhua Net" and other media reports of Wang Zhaoying's entrepreneurial story. ${ }^{[6-10]}$ The university paid 20 thousand yuan to purchase "interactive virtual campus" system developed by Bohai University college student interactive virtual reality development team.

Analysis and Evaluation Graduates' Employment. Bohai University adheres to the annual statistical analysis of the employment situation of graduates, analyze the proportion of graduates' employment, and investigate student satisfaction and enterprise satisfaction.

\section{Students' Employment of Bohai University}

Bohai University carries out an annual employment survey on March 2016, more than 2500 questionnaires were issued, and valid questionnaires were collected in 2374 copies. The main findings are as follows:

Distribution of Employer Nature. Bohai University graduates are mostly employed in private enterprises, followed by government-affiliated institutions and state-owned enterprises, foreign funded enterprises and government agencies are relatively few (Fig .1). The main reason is that Bohai 
University has many normal major, the graduates are mostly employed by schools and training institutions.

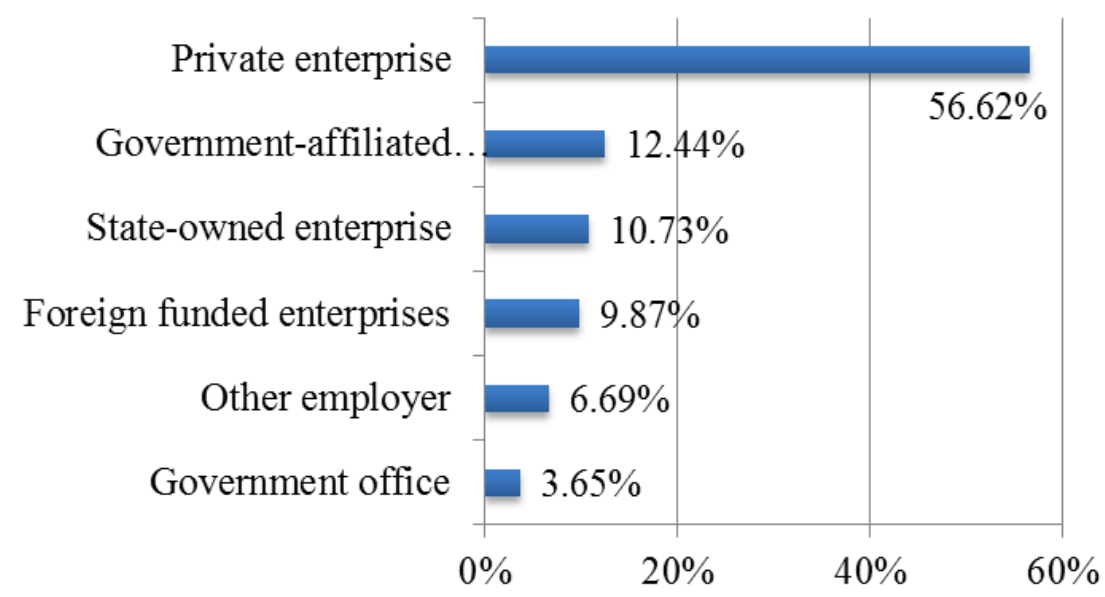

Figure 1. Distribution of employer nature of Bohai University graduates (\%)

Feelings of Salary Satisfaction. The salary satisfaction of graduates basically showed a normal distribution, $11.25 \%$ of graduates are very satisfied, $25.64 \%$ of graduates are satisfied, $44.37 \%$ of graduates are feeling all right, $13.41 \%$ of graduates are not satisfied, only $5.33 \%$ of graduates are very unsatisfied (Fig. 2).

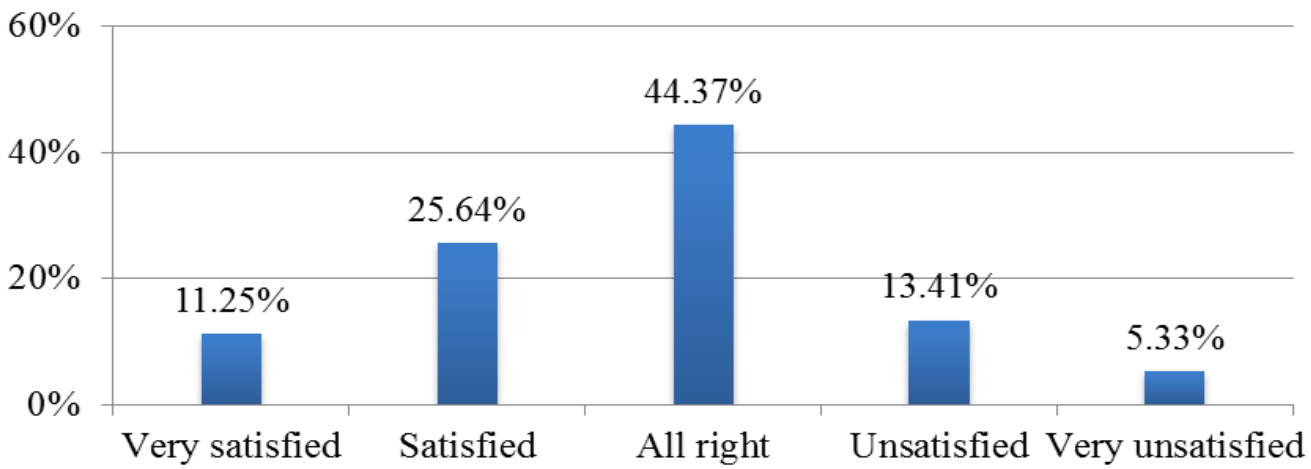

Figure 2. Feelings of salary satisfaction of Bohai University graduates (\%)

Comprehensive Evaluation from Employer. Compare to 5 years ago, employer's comprehensive evaluation of Bohai University graduates has improved, the main evaluation dimensions are listed in Table 1.

Table 1 Comprehensive evaluation from employer (full mark is 4 points)

\begin{tabular}{|l|c|c|}
\hline Evaluation Dimension & 2016 & 2011 \\
\hline Professionalism & 3.91 & 3.85 \\
\hline Working attitude & 3.86 & 3.63 \\
\hline Professional knowledge & 3.71 & 3.65 \\
\hline R \& D capability & 3.61 & 3.52 \\
\hline Cooperation spirit & 3.73 & 3.76 \\
\hline Organization skills & 3.72 & 3.67 \\
\hline Computer capability & 3.71 & 3.64 \\
\hline Foreign language ability & 3.65 & 3.61 \\
\hline Job performance & 3.83 & 3.70 \\
\hline
\end{tabular}




\section{Summary}

The talent cultivation mode reform in Bohai University has enhanced the competitiveness of students, improved the employment situation, employers' satisfaction with students also increased, some practices of Bohai University can be extend to other universities.

\section{Acknowledgements}

This research was supported by the University Basic Scientific Research Foundation of Department of Education of Liaoning Province "Research on the mechanism and countermeasures of enhancing teachers' sense of responsibility and improving teachers' professional ability (WY2016007)".

\section{References}

[1] J.J. Richter: Academic Leadership Journal in Student Research, (2015) No.3.

[2] M. Zhu, J. Zhang, S. Bao: Procedia Engineering, Vol.15 (2011) p.4173-4177.

[3] S. Hasanefendic, M. Heitor, H. Horta: Technological Forecasting and Social Change, Vol.113 (2016) p.328-340.

[4] T. Shindina, Y. Lysenko, N.Orlova: Procedia - Social and Behavioral Sciences, Vol.214 (2015) No.5, p.1098-1108.

[5] A. Adekiya, F. Ibrahimb: The International Journal of Management Education, Vol.14 (2016) No.2, p.116-132.

[6] P. Gu, M. Shen, S. Li: Research in Higher Education of Engineering, Vol.45 (2008) No.5, p.1318-1326.

[7] G.Y. Liu: Sci-Tech Information Development \& Economy, Vol.14 (2006) No.2, p.206-211.

[8] G.R. Pike, G.D. Kuh, R.C. Massamckinley: Journal of Student Affairs Research \& Practice, Vol.45 (2008) No.4, p.560-582.

[9] R. Ferguson: Nurse Education Today, Vol.16 (1996) No.5, p.373-375.

[10] V.F. Sangganjanavanich: Journal of Employment Counseling, Vol.48 (2011) No.1, p.17-26. 